\title{
JCAPS
}

\section{EXPLORING FIRST-GENERATION COLLEGE STUDENTS LEADERSHIP BEHAVIORS AND ACTIONS DURING INTRAMURAL SPORTS}

\author{
Joseph Milone, Southern Connecticut State University
}

\begin{abstract}
College graduates need to have specific leadership-related skills, behaviors, and traits when entering the workforce. Campus involvement is one way for students to develop such areas. Therefore, this qualitative study explored the self-reported leadership skills of first-generation college students who were actively participating in intramural sports. Twelve students from a 4-year public university in the Northeast were interviewed about the research-driven photographs they submitted depicting leadership skills they engaged in during intramural sports participation. Photograph captions and interviews were analyzed using Kouzes and Posner's (2014) leadership model. Findings revealed that students reported engaging in behaviors and actions aligned with the leadership practices described by Kouzes and Posner (2014). These findings can help inform the decisions campus recreation professionals make about the role leadership development plays in program offerings.
\end{abstract}

\section{INTRODUCTION}

BUSINESS AND INDUSTRY LEADERS have emphasized the need for new college graduates to be prepared with leadership-related skills before entering the workforce (Association of American Colleges and Universities [AACU], 2013; Casner-Lotto, 2006; National Association of Colleges and Employers [NACE], 2014). The leadership skills emphasized by these leaders are directly connected to the skills identified in the organizational leadership literature about how to be an effective leader (Avolio, Gardner, Walumbwa, Luthans, and May, 2004; Yukl, 2009). Nevertheless, findings from related research suggested that many recent 2-year and 4-year college graduates are deficient in leadership-related skills after completing college (AACU, 2013; American Society for Training and Development [ASTD], 2012; Casner-Lotto, 2006; Deloitte, 2011).

Colleges and universities have a responsibility to address the deficiency in college students' leadership skills. Astin and Astin (2000) suggested that higher education plays a significant role in influencing the quality of leadership in today's society. Providing opportunities for students to become involved in non-academic activities is one of many ways colleges and universities can begin to increase students' leadership capacities so that their graduates meet the needs described by business and industry leaders.

Therefore, the purpose of this case study was to explore the self-reported leadership skills of first-generation college students who were actively participating in intramural sports. Specifically, the research aimed to describe participants' reports of engaging in behaviors or actions during intramural sports aligned with the leadership practices described by Kouzes and Posner (2014). The study used two data collection methods: participant submitted research-driven photographs and semi-structured interviews. 


\section{Student Involvement/Engagement in Non-Academic Activities}

Since one of the goals of higher education is to foster and develop future leaders, it is necessary to understand how in-class and out-of-classroom experiences may influence leadership skill development (Hall, Forrester, \& Borsz, 2008). The results of related research supported the notion that involvement in non-academic activities such as clubs, intramurals, campus programming, campus governance, and fraternities and sororities can help students gain leadership skills and confidence that will be useful in their future endeavors (Dugan, 2011; Magolda, 2005). Specifically, research has shown that college students' involvement in these types of activities presents opportunities for them to develop leadership-related skills by combining their academic learning with activities outside the classroom (Astin \& Astin, 2000). Dugan, Torrez, \& Turman (2014) reported that intramural sports provide a "powerful platform through which to reach students" (p. 11) for learning opportunities, based on the large number of students reporting some level of involvement.

In a study of 35,000 students who participated in the National Intramural, Recreation, and Sports Association (NIRSA)/NAPSA Consortium Nationwide Survey, 75\% of respondents indicated they used on-campus recreation center facilities, programs, and services (Forrester, 2014). Additionally, 64\% of respondents noted that participation in campus recreation services provided them with skills that they could use after graduation, including group cooperation, communication, multicultural awareness, and problem-solving (Forrester, 2014). Campus recreation centers afford students non-academic educational experiences during which they have opportunities to (a) develop positive self-esteem; (b) improve their social relationships; and (c) enhance their leadership, communication, and problem-solving skills (Dalgarn, 2001). This research suggested that student leadership skill-development may be facilitated by participation in experiential learning opportunities, such as intramural sports.

Researchers have identified a need for additional exploration of college student leadership in non-academic activities (Busseri \& Rose-Krasnor, 2008; Dugan, 2006; Hall et al., 2008). Although research has been conducted to investigate college students' leadership skills while participating in non-academic activities (Cress, Astin, Zimmerman-Oster, \& Burkhardt, 2001; Dugan, 2006; Dugan \& Komives, 2010; Hall et al., 2008; Logue, Hutchens, \& Hector, 2005), including intramural sports (Dugan et al., 2014), there seems to be a shortage of research on the self-reported leadership skills of first-generation college students who were actively participating in intramural sports. A study by Dugan, Turman, and Torrez (2015) related to leadership and intramural sports included first-generation college students. However, the designation of being first-generation was found not to be statistically significant.

\section{First-Generation College Students}

For the academic year 2011-12,33\% of the students enrolled in postsecondary education were first-generation (Cataldi, Bennett, \& Chen, 2018). Choy (2001) noted that students of parents who never went to college were less likely to be successful in college than students whose parents completed their undergraduate studies. In college, first-generation college students also face isolation, influencing their involvement, engagement, and persistence (Jehangir, Williams, \& Jeske, 2012). Involvement in campus organizations and the campus environment are important factors in first-generation college students' social integration on college campuses (Woosley \& Shepler, 2011). First-generation college students also have been found to socialize less while on campus because of job responsibilities (Terenzini, Springer, Yaeger, Pascarella, \& Nora, 1996). Given what is known about leadership development and involvement in non-academic activities, a study focused on first-generation students would potentially inform current understanding of the ways to promote students' leadership skill development and better prepare them for the workforce.

\section{CONCEPTUAL FRAMEWORK}

The operationalization of the construct of leadership for this study was derived from Kouzes and Posner's (2014) Student Leadership Challenge: Five Practices for Becoming an Exemplary Leader. Kouzes and Posner's (2014) model was selected because it was grounded in research (Posner, 2004, 2009), emphasized that leadership development is self-development, and embodies some of the same leader behaviors that can be developed through intramural sports participation (Forrester, 2014). Through over 25 years of analyzing personal-best leadership experiences, Kouzes and Posner identified Five Practices of exemplary leaders: (a) Model the Way, (b) Inspire a Shared Vision, (c) Challenge the Process, (d) Enable Others to Act, and (e) Encourage the Heart. As defined by 
these authors, practices are behaviors and actions that are developable and available to anyone who wants to take on the challenge of leading.

For each of the Five Practices, Kouzes and Posner (2014) identified related commitments (i.e., behaviors) that provide a framework, or template, for understanding exemplary leadership and learning how to lead. Table 1 briefly outlines each of the Five Practices and their corresponding commitments.

Table 1. Student leadership challenge: practices and commitments.

\begin{tabular}{|l|l|}
\hline Practices and Commitments & Description \\
\hline Model the Way & Leaders discover who they are and what they believe in. \\
\hline Clarify Values & Leaders find their voice and affirm shared values. \\
\hline Set the Example & Leaders live the shared values and teach others to model the values. \\
\hline Inspire a Shared Vision & $\begin{array}{l}\text { Leaders promote a shared vision that communicates to the group that their } \\
\text { values and interests are important. }\end{array}$ \\
\hline Envision the Future & Leaders imagine the possibilities and find a common purpose. \\
\hline Enlist Others & Leaders appeal to common ideals and animate the vision. \\
\hline Challenge the Process & $\begin{array}{l}\text { Leaders encourage innovation and risk-taking to produce small wins and } \\
\text { learning opportunities for the group. }\end{array}$ \\
\hline Search for Opportunities & Leaders seize the initiative and exercise outsight. \\
\hline Experiment and Take Risks & Leaders generate small wins and learn from experience. \\
\hline Enable Others to Act & $\begin{array}{l}\text { Leaders encourage a team effort and allow for trust and relationship building } \\
\text { within the group. }\end{array}$ \\
\hline Foster Collaboration & Leaders create a climate of trust and facilitate relationships. \\
\hline Strengthen Others & Leaders enhance self-determination and coach for competence and confidence. \\
\hline Encourage the Heart & Leaders inspire their team and express satisfaction in the groups' successes. \\
\hline Recognize Contributions & Leaders expect the best and personalize recognition. \\
\hline Celebrate Values and Victories & Leaders create a spirit of community and personally get involved. \\
\hline
\end{tabular}

\section{METHODS}

A single-case study design was selected to answer the research questions for this exploratory research. Yin (2014) stated that a case study design is appropriate when the researcher has little or no control over the study conditions. The investigation is focused on a contemporary set of events. The purpose of this investigation was the self-reported leadership skills of first-generation college students who actively participated in intramural sports. This study was focused on a recent event at a university in New England, namely first-generation college students' participation in intramural sports. The researcher had no control over how participants might report on the leadership skills they engaged in during intramural sports. Thus, a case study design was appropriate. Yin's case-study design guided the validity and reliability of this investigation.

\section{Data Collection}

Students who volunteered for the study submitted a research-driven photograph and participated in a semi-structured interview focused on their personal-best leadership experiences related to intramural sports participation. Students were asked to email a photograph with a caption or brief description about how the photograph depicted the leadership skills they believed they engaged in while participating in intramural sports. The informed consent and follow-up emails explained to students they could be in the photo but should not include other people. In addition, participants gave permission for the photograph to be published in presentations, reports, or other write-ups about the research and that their name or identity would not be associated with the photo in any way. The photographs served as the focus of the in-person interviews. 
The goal of the interview was to elicit information from participants about their personal-best leadership experiences during intramural sports participation. The interview guide was explicitly designed to help explore the meaning of the photograph. The interview questions were developed based on Tinkler's (2013) suggestion that "talk is usually the best way to explore what a photo means to the photographer because what is seen by one person is not always visible to another" (p. 171).

Upon receipt of a participant's photograph, an email was sent to set a mutually agreed upon date, time, and location for the interview. When the researcher and interviewee arrived at the interview site, the researcher handed a copy of the interview questions to the participant. Interviews lasted about 30 minutes. The confidentiality of the participants was maintained throughout this study. Electronic and paper materials were not coded in any identifiable way. The participants in this study were assigned pseudonyms for all write-ups to protect their identities.

\section{Participant Recruitment}

Two sampling strategies were applied-purposeful and convenience (Bryman, 2012). The setting for this study was a public four-year institution in the Northeast United States. The sample for this study was purposely recruited from the population of first-generation college students who were enrolled at the University at the time of the study and actively participated in at least one intramural sport. Recruitment strategies included posted fliers in the student center, athletic complex, and dormitories. The Office of Campus Recreation assisted by emailing the flier to students who were registered for intramurals. The Office of Residence Life also posted information about the study on digital display boards in residence halls. Study recruitment also took place over two weeks at the site of the intramural sports activity. To attract participation, students that volunteered for the study were entered to win one of two \$25 Amazon gift cards.

\section{Sample Description}

In all, 12 students agreed to participate in the study. Table 2 summarizes the demographic information about participants.

Table 2. Sample characteristics.

\begin{tabular}{|l|l|l|}
\hline Characteristic & $\mathrm{n}$ & $\%$ \\
\hline $\begin{array}{l}\text { Semesters Participating in } \\
\text { Intramurals Sports }\end{array}$ & & \\
\hline $1-2$ & 7 & 58 \\
\hline $3-5$ & 2 & 17 \\
\hline $6-8$ & 3 & 25 \\
\hline Intramural Sports Participation & & \\
\hline Dodgeball & 9 & 75 \\
\hline Flag Football & 4 & 33 \\
\hline Basketball & 2 & 17 \\
\hline Volleyball & 3 & 25 \\
\hline Softball & 3 & 25 \\
\hline Soccer (indoor/outdoor) & 3 & 25 \\
\hline Floor Hockey & 1 & 8 \\
\hline Class Level & & \\
\hline Freshman & 4 & 33 \\
\hline Sophomore & 2 & 17 \\
\hline Junior & 1 & 8 \\
\hline Senior & 5 & 42 \\
\hline Live on Campus & & \\
\hline Yes & 8 & 67 \\
\hline No & 4 & 33 \\
\hline
\end{tabular}

Note. For the category intramural sports participation, totals exceeded more than 12 because students were asked to list all intramural sports they had participated in.

\section{Data Analysis}

Each participant $(\mathrm{N}=12)$ submitted a captioned photograph depicting leadership skills he or she believed they engaged in through participation in intramural sports. The photographs were labeled and sorted according to features they had in common (e.g., images that only contained an object). Finally, each photograph was examined together with the participant-supplied caption to gain a sense of the meaning of the picture as it pertained to the study's purpose. Specifically, captions were read several times to identify words or short phrases that captured the essence of Kouzes and Posner's (2014) leadership practices.

Each student's photograph was used as a prompt for the student's in-person interview. The interviews lasted between 16 and 30 minutes, were digitally recorded, and verbatim transcripts were created. Transcripts were coded following Creswell's (2009) steps for analyzing qualitative data. Specifically, sections of text were hand-coded to the descriptors of Kouzes and Posner's (2014) leadership model and to how students perceived they had engaged in the leadership skills they described. 


\section{RESULTS}

The results of the interview analysis are presented together with representative quotes. A sampling of photographs is included and captioned with keywords that participants used as they talked about their pictures and discussed what the photographs meant to them.

\section{Participant-Submitted Research-Driven Photograph}

The analysis of the participant-generated research-driven photographs depicting leadership skills students believed they engaged in through participation in intramural sports yielded the following results about the subject of the images and places depicted. The subject of the images clustered into three main categories: (a) participants $(\mathrm{n}=4 ; 33 \%)$, (b) object alone $(\mathrm{n}=5 ; 42 \%)$, or (c) participant and object $(\mathrm{n}=3 ; 25 \%)$. Table 3 summarizes the frequencies and percentages of the analysis of participant supplied captions. Participants most often used words and phrases that captured the essence of Kouzes and Posner's (2014) leadership practice Model the Way. No photographs with a caption could be categorized to the leadership practice Challenge the Process.

Table 3. Analysis of participant captions: frequencies and percentages

\begin{tabular}{|l|l|l|}
\hline & $\mathrm{n}$ & $\%$ \\
\hline Leadership Practice & & \\
\hline Model the Way & 6 & 50 \\
\hline Inspire a Shared Vision & 2 & 17 \\
\hline Enable Others to Act & 1 & 8 \\
\hline Encourage the Heart & 1 & 8 \\
\hline Unidentifiable & 2 & 17 \\
\hline
\end{tabular}

\section{In-Person Interview}

Model the Way. During the interviews, all the participants $(\mathrm{N}=12)$ talked about behaviors or actions categorized as containing elements of the leadership practice Model the Way. As students spoke about their intramural sports participation, they drew on their current experiences and talked about earlier experiences from high school, former sports endeavors, and life.

All participants $(\mathrm{N}=12)$ described behaviors or actions that suggested they applied the commitment Set the Example. Kouzes and Posner (2014) noted that an important aspect of the commitment Set the Example is a leader's credibility. The authors noted that credibility is judged by what leaders say, how they act, and how they spend their time. During the interviews, students most often talked about understanding the importance of how their actions influence those around them. Student-10, depicted in Figure 1, talked about how he aligned his actions with his values. He mentioned how he dressed "professionally" to be taken "seriously" by his team. He spoke about how the photograph he submitted represented his "serious look" to the "outside world" and that dressing professionally gave his teammates confidence that he is "the guy to go to." When describing how dressing professionally helps "Set the Example," he stated,

You know what, intramurals is a team sport, just like any other sport. It doesn't matter [what] the level is; it just shows that you need leadership, and with leadership, you need to look at the person and know they are serious enough that they can lead you.

Student-7, depicted in Figure 2, submitted a photograph of him whitewater kayaking. As he viewed the photograph during the interview, he explained that a leader's actions and words could create a "positive splash" that "cause positive ripples." He continued by stating that leaders can make positive or negative ripples depending on their actions:

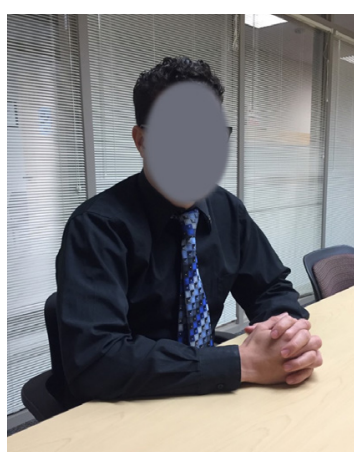

Figure 1.

Photograph submitted by Student-10. 
[The photograph] doesn't physically show depicting leadership skills, but it's kind of a metaphor. In this picture, I wasn't the leader, but you see the qualities of a leader. I made a splash, and it's causing ripples, and it depends on the kind of splash that you make on the team. You know you can make a splash, and people [will] not like you. You can be a negative kind of person, and if you make a negative splash, you are going to make negative ripples. It's going to have negative effects. So it depends, you have to lead a certain way to get the best results.

In the commitment Set the Example, Kouzes, and Posner (2014) described that stressful or challenging situations offer opportunities for a leader to lead by example. Student-6 submitted a picture of pencils, as seen in Figure 3, to illustrate how a leader "steps up" in certain situations. A senior and quarterback of his flag football team, Student-6 talked about how in group situations, "there's always going to be a leader, and there's always people who listen." He stated he set the example by staying "calm." He continued, "I think [as a leader] you just have to stay calm. If you try to get too ahead of yourself or try to think too much, [the play] usually doesn't work out, and [you] make mistakes."

Six participants (50\%) described behaviors or actions that suggested they applied the commitment Clarify Values. For the commitment Clarify Values, Kouzes and Posner (2014) noted that values influence every part of a person's life and guide their actions. Student-8, a former collegiate baseball player, talked about his "love" for the game and how it was "more than just a sport," it was a "way of life." As he looked at the photograph of himself playing baseball (Figure 4), he described how it portrayed values such as "hard work, dedication, perseverance, and heart." He said he tries to bring those values to intramural sports through his actions. Student- 8 continued by saying,

I try to do that by my actions, by the way I carry myself while I play the sport. If I find something that I think [will help] someone do better, I give them that information.

Inspire a Shared Vision. During the interviews, nine participants $(\mathrm{N}=12)$ talked about behaviors or actions categorized as containing elements of the leadership practice Inspired a Shared Vision. Eight participants (67\%) described behaviors or actions that suggested they applied the commitment Enlist Others. Fundamental to the practice Inspire a Shared Vision and specifically to the commitment Enlist Others is practicing positive communication (Kouzes \& Posner, 2014). Five participants $(\mathrm{N}=12)$ mentioned the importance of using positive communication when playing intramurals. Student-9 reflected on the photograph of the championship towel, depicted in Figure 5. She received it for being part of an intramural softball team. She explained that the picture reminded her of the positive communication she contributed to the team. Student-9 said, "I always stay positive, I guess. That's my little leader part." She gave an example of her positive communication during those games:

If one of the players popped-out or something, I would cheer them up and say, ok you will get it back next time.... [or] you guys got this.... I feel like whenever I would be positive, [the game] would take a turn and we would end up winning at the end. Everyone would just be so happy afterwards.

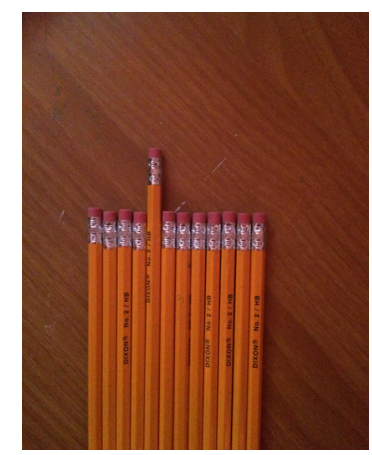

Figure 3.

Photograph submitted by Student-6.

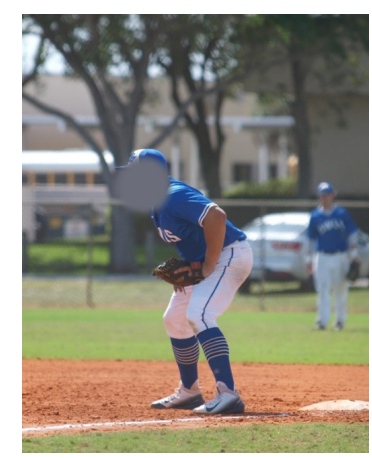

Figure 4.

Photograph submitted by Student-8. 
Five students (42\%) described behaviors or actions that suggested they applied the commitment Envisions the Future. An important element of the commitment Envision the Future is getting everyone on the same page and going in the same direction (Kouzes \& Posner, 2014). This is how Student-10, who has participated in seven different intramural sports and is a leader in his fraternity, described how to get new players to "buy-in" to the team approach. Student-10 explained, "once you talk to them and you explain yourself, they see that's the best way to win. They are going to buy-in instantly because the goal is to win, and that's what they want to do."

Challenge the Process. During the interviews, nine participants $(\mathrm{N}=12)$ described behaviors or actions that could be categorized as containing elements of the leadership practice Challenge the Process. Describing the leadership commitment Search for Opportunities, Kouzes and Posner (2014) noted that leaders look for ways to improve and do things differently. Six participants (50\%) described behaviors or actions that suggested

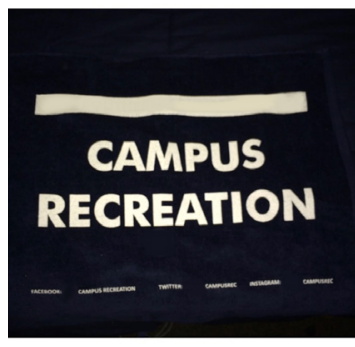

Figure 5.

Photograph submitted

by Student-9. they applied the commitment Search for Opportunities. Regarding this commitment, three students $(\mathrm{N}=12)$ often spoke about getting to know their players so they could identify strategies to win the game. For example, Student-3 mentioned he does this by watching what is happening on the court. He continued, "[I try] to set up strategies, like if it's three on two, I try to get all the balls on our side and attack like that." Student-3 described how he observes the other team give his team "a scouting report." He noted that he assesses his teams' "strengths" and weaknesses" so they can come up with the best plan to win the game. He finished by saying that before a game, "I try to show [my team] the best spots to hit them and point out who the strongest players are and the weakest players are."

Six participants (50\%) described behaviors or actions that suggested they applied the commitment Experiment and Take Risks. A component of the commitment Experiment and Take Risks is learning from one's mistakes (Kouzes \& Posner, 2014). For this commitment, three students $(\mathrm{N}=12)$ talked about how they found different ways to win during intramural sports. After one of his intramural soccer games, Student-7 explained to his team, even though they won, "there were certain little things if we cut [them] out, we would do much better." He discussed different ways the team could "clean up" or "change" some of their play to do better. He finished by stating that the group cleaned up their play and "responded perfectly. They did exactly what I said would help. We had fun and won even better."

Enable Others to Act. During the interviews, all of the participants $(\mathrm{N}=12)$ described behaviors or actions that could be categorized as containing elements of the leadership practice Enable Others to Act. All of the participants $(\mathrm{N}=12)$ talked behaviors or actions that suggested they applied the commitment Foster Collaboration. Describing the commitment Foster Collaboration, Kouzes and Posner (2014) noted that leaders need to facilitate relationships within the group or team. Four students $(\mathrm{N}=12)$ talked about how intramural sports helped build relationships. For example, Student-3, depicted in Figure 6, talked about how his "outfit" in the photograph facilitated a sense of "unity" and connection among the members of his dodgeball team. He went on to explain in detail how his style helps facilitate relationships with those around him:

I went out this weekend and bought a whole bunch of bandanas, so we are all wearing bandanas.... My roommate is on the team, and he bought a whole bunch of bandanas. The kids across the hall bought a whole bunch of bandanas. It's basi-

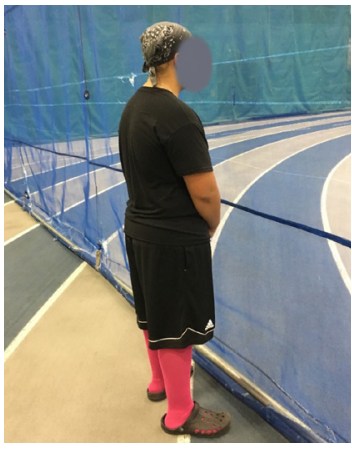

Figure 6.

Photograph submitted by Student-3. cally unity with the bandanas. I think it shows my leadership [because] I started the bandana thing and they just chimed in on it. Right, so it shows I am not afraid to be different from other people. I help show them their unique side as well.

To demonstrate the commitment Foster Collaboration, leaders also must listen to members of the group, be open to different points of view, and make people feel like they are part of the team (Kouzes \& Posner, 2014). Five students $(\mathrm{N}=12)$ talked about giving everyone an opportunity to contribute. Student- 2 mentioned, even though 
as a leader he makes the final decision, he wants to "hear everyone's ideas." He explained,

I want to hear from everyone. I want to hear everyone's ideas. That person that you shut out or don't listen to, they could have an awesome idea. When I am going to make a decision, I want to hear people's opinions.

Nine participants (75\%) described behaviors or actions that suggested they applied the commitment Strengthen Others. To establish the commitment, Strengthen Others, leaders need to coach and mentor others to help them grow and develop their potential (Kouzes \& Posner, 2014). Six students $(\mathrm{N}=12)$ mentioned that they took on the role of coach or mentor during intramurals. Student-3 noted how he communicated with a player on his dodgeball team to get his head back into the game after being the first person out. He explained,

We just talked to him about it and [said] you just need to relax and get your head back in the game and do better. He actually won the second game for us. I feel like we always have each other's back.

Encourage the Heart. During the interviews, ten of the participants $(\mathrm{N}=12)$ talked about behaviors or actions that could be categorized as containing elements of the leadership practice Encourage the Heart. Describing the commitment Recognize Contributions, Kouzes and Posner (2014) mentioned the need for leaders to connect with group members and get close to people to build trust and loyalty. Seven participants (58\%) described behaviors or actions that suggested they applied the commitment Recognize Contributions. During the interview, Student- 4 expressed the importance of how intramurals allows people to develop bonds and loyalty. He said the photograph, in Figure 7, shows him "picking up" his teammate who has been with him "for all these years." He mentioned that they are "happy" and "excited" because they are in the regional intramural football championship game "together." Student-4 explained that,

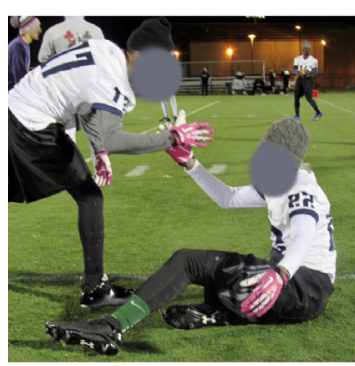

Figure 7.

Photograph submitted by Student-4.

you look at our faces, we are smiling, cheesing, and we are just happy to be there. I think it shows our loyalty to each other and to the team. We did not give up on each other. ... I have my friends with me. We were finally coming together as one at the moment. . . Intramural sports definitely helped us get together as one. It's all about loyalty. . . I It's all about connections and it's an interesting way to meet people all through flag football.

Six participants (50\%) described behaviors or actions that suggested they applied the commitment Celebrate Values and Victories. Showing you care and getting personally involved are essential parts of the commitment Celebrate Values and Victories (Kouzes \& Posner, 2014). Three students $(\mathrm{N}=12)$ talked about ways they care for their teammates and how they get personally involved. For example, Student-2, pictured in Figure 8, talked about how the photograph shows how he becomes involved by supporting his dodgeball team in all situations. He mentioned, whether he was in the game or on the sideline, his job was to "pick up our team and cheer them on" by providing encouraging words such as "good job!" and "keep it going." He also said, "a team can only go as far as its supporters." He said the photograph was an example of the type of support he gave during his first official dodgeball game. He explained,

We had all the components of a functioning team - support, hard work.... I think the picture shows [how I] basically look on the sidelines supporting my team. I [have] my arms up, I am happy, and [I am] trying to keep my teammates in the game mentally.

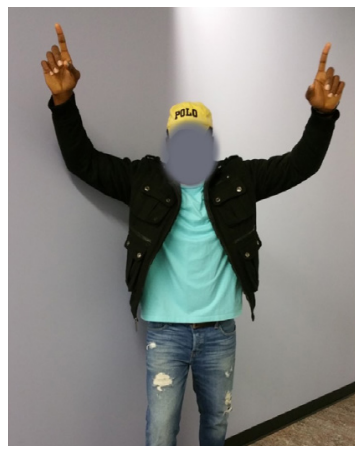

Figure 8 .

Photograph submitted by Student-2. 


\section{CONCLUSIONS AND IMPLICATIONS FOR PRACTICE AND FUTURE RESEARCH}

The purpose of this case study was to explore the self-reported leadership skills of first-generation college students who were actively participating in intramural sports. Specifically, the research aimed to describe participants' reports of engaging in behaviors or actions, during intramural sports, that are aligned with the leadership practices described by Kouzes and Posner (2014). Overall, findings from the analysis of the data collected from photographs and interviews revealed that students most often reported engaging in leadership behaviors or actions related to Enable Others to Act followed by Model the Way, Encourage the Heart, Inspire a Shared Vision, and then Challenge the Process. Specially, students most often talked about: (a) treating others with respect and fostering collaborative relationships, (b) coaching or mentoring others during intramural sports, (c) being open to diverse points of view (d) recognizing, encouraging, and praising their teammates contributions, (e) building trust and loyalty, and (f) leading by example during intramural participation.

\section{Implications for Practice}

Based on the findings and conclusions from this study, two recommendations for practice were made. Notably, the study participants reported engaging in leadership actions and behaviors aligned with Kouzes and Posner (2014) leadership model during intramural sports. This suggests that intramural sports provide an opportunity for students to practice leadership skills. Given the importance of new college graduates to possess leadership skills wanted by business and industry (Casner-Lotto, 2006), campus recreation professionals should consider providing students opportunities to develop leadership skills through participant discussions about their leadership capacities and experiences in relationship to activity involvement, including intramural sports. Campus recreation professionals should explore different leadership development models and research with students. McFadden and Stenta (2015) noted that campus recreation professionals could introduce leadership frameworks into their programs to encourage the development of student leadership capacity. Activities provided by campus recreation departments should also give students the opportunity to assess their own leadership skills and be able to share those skills and experiences with their peers and campus recreation staff. The workshops would allow students with strong leadership capacities to participate in their own leadership development and would allow others to learn about the leadership skills that they might need as leaders in their careers.

College administrators should also provide campus recreation staff with professional development opportunities related to student leadership development. This recommendation is premised on the fact that the campus recreation department implemented the intramural sport programs in which students in this study reported engaging in leadership behaviors or actions as described by Kouzes and Posner (2014). Jones, Harper, and Schuh (2011) noted that professional development is important to the future of student affairs because the profession relies on learning more about the students they serve and new ways to engage students outside of the classroom. In addition to understanding how students develop leadership skills, the professional development training could also enhance the leadership skills of campus recreation staff. By understanding their own leadership experiences, skills, and behaviors, staff could find ways to relate their leadership identity to their job and to the students they serve.

\section{Future Research}

Based the findings of this study and the dearth of empirical studies that have examined the reported leadership skills of first-generation college students who were actively participating in intramural sports, other researchers should repeat this study at different institutions. Similar studies may lead to a deeper understanding of first-generation college students' leadership experiences in intramural sports. Researchers should conduct a similar study using researcher observations and focus groups as the data collection methods. The inclusion of researcher observations would offer an opportunity to assess whether students are engaging in the reported leadership skills. Finally, a study comparing first-generation students and non-first generation students' reports of leadership behaviors and actions in which they engage during intramural sports would add to the literature of college student leadership development. It might also be able to explore more deeply the different leadership experiences of these populations. 


\section{LIMITATIONS}

The researcher has identified three potential limitations of this study. First, the researcher was a part-time faculty member at the University at the time of the study. Although this could have encouraged participation in the study, it also had the potential to make participants concerned about their confidentiality. Additionally, because the interview was completed in the presence of the researcher, a participant might complete the in-person interview by providing responses designed to please the researcher rather than giving an honest account of their personal-best leadership experiences while participating intramural sports.

Second, findings from a case study cannot be generalized to a larger population (Yin, 2014). Therefore, the findings from this study will only be generalizable to the leadership model (Kouzes \& Posner, 2014) and the phenomenon being explored, the self-reported leadership skills of first-generation college students who were actively participating in intramural sports.

Third, the findings from this study may not be generalizable to other colleges and universities. It will be up to the reader to decide whether the findings from this study can be generalizable to their setting.

\section{CONCLUSION}

Campus recreation, and intramural sports, allows students to become involved and engaged on college campuses. These services provide one venue in which first-generation college students engage in and practice their leadership skills and behaviors. While campus recreation professionals have the training, knowledge, and skills to provide quality programming for students, it is the hope that the findings of this study can help inform the decisions they make about the role leadership development plays in program offerings.

\section{REFERENCES}

American Society for Training \& Development. (2012). Bridging the skills gap. Help wanted, skills lacking: Why the mismatch in today's economy? Retrieved from http://nist.gov/mep/upload/Bridging-the-Skills-Gap_2012.pdf

Association of American Colleges and Universities. (2013). It takes more than a major: Employer priorities for college learning and student success. Retrieved from http://www.aacu.org/sites/default/files/files/LEAP/2013_ EmployerSurvey.pdf

Astin, A. W., \& Astin, H. S. (2000). Students have the power to lead. In Leadership reconsidered: Engaging higher education in social change (pp. 17-31). Retrieved from http://eric.ed.gov/?id=ED444437

Avolio, B. J., Gardner, W. L., Walumbwa, F. O., Luthans, F., \& May, D. R. (2004). Unlocking the mask: A look at the process by which authentic leaders impact follower attitudes and behaviors. The Leadership Quarterly, 15(6), 801-823.

Bryman, A. (2012). Social research methods (4th ed.). New York, NY: Oxford University Press.

Busseri, M. A., \& Rose-Krasnor, L. (2008). Subjective experiences in activity involvement and perceptions of growth in a sample of first-year female university students. Journal of College Student Development, 49(5), 425-442

Casner-Lotto, J. (2006). Are they really ready to work? Employers perspectives on the basic knowledge and applied skills of new entrants to the 21st century U.S. workforce.

Cataldi, E.M., Bennett, C.T., \& Chen, X. (2018). First-generation students: College access, persistence, and postbachelor's outcomes (NCES 2018-421). U.S. Department of Education. Washington, DC: National Center of Education Statistics. Retrieved from: https://nces.ed.gov/pubs2018/2018421.pdf

Choy, S. P. (2001). Students who did not go to college: Postsecondary access, persistence, and attainment (NCES 2001-126). Washington, DC: Government Printing Office.

Cress, C. M., Astin, H. S., Zimmerman-Oster, K., \& Burkhardt, J. C. (2001). Developmental outcomes of college students' involvement in leadership activities. Journal of College Student Development, 42(1), 15-27. 
Creswell, J. W. (2009). Research design: Qualitative, quantitative, and mixed methods approaches (3rd ed.). Los Angeles, CA: Sage.

Dalgarn, M. K. (2001). The role of the campus recreation center in creating a community. NIRSA, 25(1), 66-72.

Deloitte. (2011). Boiling point? The skills gap in U.S. manufacturing. Retrieved from http://www.themanufacturinginstitute.org/ /media/A07730B2A798437D98501E798C2E13AA.ashx

Dugan, J. P. (2006). Involvement and leadership: A descriptive analysis of socially responsible leadership. Journal of College Student Development, 47(3), 335-343.

Dugan, J. P. (2011). Students' involvement in group experiences and connections to leadership development. New Directions for Institutional Research, 17-32.

Dugan, J. P., \& Komives, S. R. (2010). Influences on college students' capabilities for socially responsible leadership. Journal of College Student Development, 51(5), 525-549.

Dugan, J. P., Torrez, M. A., \& Turman, N. T. (2014). Leadership in intramural sports and club sports: Examining influences to enhance educational impact. Corvallis, OR: NIRSA.

Dugan, J.P., Turman, N.T., \& Torrez, M.A. (2015). When recreation is more than just sport: Advancing the leadership development of students in intramurals and club sports. Recreational Sports Journal, 39(2), 37-48.

Forrester, S. (2014). The benefits of campus recreation. Corvallis, OR: NIRSA. Retrieved from http://rfc.wayne. edu/mort-harris/forrester_2014-report.pdf

Hall, S. L., Forrester, S., \& Borsz, M. (2008). A constructivist case study examining the leadership development of undergraduate students in campus recreational sports. Journal of College Student Development, 49(2), 125-140.

Jehangir, R., Williams, R., \& Jeske, J. (2012). The influence of multicultural learning communities on the intrapersonal development of first-generation college students. Journal of College Student Development, 53(2), 267-284.

Jones, S.R., Harper, S.R., \& Schuh, J.H. (2011). Shaping the Future. In J.H. Schuh, S.R. Jones, S.R. Harper, \& associates (Eds.), Student Services: A handbook for professionals (5th ed., pp. 534-546). San Francisco, CA: Jossey-Bass

Kouzes, J. M., \& Posner, B. Z. (2014). The student leadership challenge: Five practices for becoming an exemplary leader (2nd ed.). San Francisco, CA: Wily.

Logue, C. T., Hutchens, T. A., \& Hector, M. A. (2005). Student leadership: A phenomenological exploration of postsecondary experiences. Journal of College Student Development, 46(4), 393-408.

Magolda, P. (2005). Promoting student success: What student leaders can do (Occasional Paper No. 8). Bloomington, IN: Indiana University Center for Postsecondary Research.

McFadden, C.W., \& Stenta, D.A. (2015). Connecting collegiate recreation and athletics to leadership. New Directions for Student Leadership, 147, 5-18.

National Association of Colleges and Employers. (2014). The job outlook for the class of 2014. Retrieved from www.nacaweb.org

Posner, B. Z. (2004). A leadership development instrument for students: Updated. Journal of College Student Development, 45(1), 443-456.

Posner, B. Z. (2009). Understanding the learning tactics of college students and their relationship to leadership. Leadership and Organizational Development Journal, 30(4), 386-395.

Terenzini, P. T., Springer, L., Yaeger, P. M., Pascarella, E. T., \& Nora, A. (1996). First-generation college students: Characteristics, experiences, and cognitive development. Research in Higher Education, 37(1), 1-22.

Tinkler, P. (2013). Using photographs in social and historical research. Los Angeles, CA: Sage

Woosley, S. A., \& Shepler, D. K. (2011). Understanding the early integration experiences of first-generation college students. College Student Journal, 45(4), 700-714.

Yin, R. K. (2014). Case study research: Design and methods (5th ed.). Los Angeles, CA: Sage.

Yukl, G. (2009). Leading organizational learning: Reflections on theory and research. The Leadership Quarterly, 20, 49-53. 